\title{
Validity Evidence of the Brazilian Version of the Mindful Attention Awareness Scale (MAAS)
}

\author{
Evidências de Validade da Versão Brasileira da Escala de Atenção \\ e Consciência Plenas (MAAS)
}

\author{
Víviam Vargas de Barros*, ${ }^{*}$, Elisa Harumi Kozasa ${ }^{b, c}$, Isabel Cristina Weiss de Souza ${ }^{a, c}$ \\ \& Telmo Mota Ronzani ${ }^{a}$ \\ ${ }^{a}$ Universidade Federal de Juiz de Fora, Juiz de Fora, MG, Brasil, \\ ${ }^{b}$ Hospital Israelita Albert Einstein, São Paulo, SP, Brasil \\ $\&{ }^{c}$ Departamento de Psicobiologia da Universidade Federal de São Paulo, São Paulo, SP, Brasil
}

\begin{abstract}
Mindfulness is a skill that allows the practitioner to expand an existing space between stimulus and response, so he/she may make more conscious choices which in turn prevents the perpetuation of dysfunctional patterns of behaviors, contributing to the improvement of his/her well-being. The goal of this study was to evaluate the psychometric properties of the Brazilian version of the Mindful Attention Awareness Scale (MAAS) in a sample with 395 participants divided into smokers, people from the general population, college students and meditators. They answered the MAAS and the Psychological Well-Being Scale (PWBS). An exploratory factor analysis was conducted to test the factor structure of the MAAS. Internal consistency, test-retest reliability and split half were respectively assessed with Cronbach's $\alpha$ and correlation coefficients. Construct validity was examined by correlating the MAAS with psychological well-being. Criterion validity was assessed by comparing the meditators' scores on the MAAS with the scores of other participants. After the exploratory factor analysis, the Brazilian MAAS remained a unidimensional scale. Reliability $[\alpha=.83$; split half $=.67$ and test-retest $=.80(p<.001)]$ and validity measures were adequate, except the criterion validity which was not confirmed in the mentioned sample.

Keywords: Mindfulness, MAAS, psychometry.
\end{abstract}

\begin{abstract}
Resumo
Mindfulness é uma habilidade que permite ao praticante a ampliação de um espaço existente entre um estímulo e a resposta, podendo o mesmo fazer escolhas mais conscientes e impedindo a perpetuação de padrões de comportamentos disfuncionais, contribuindo para a melhora de seu bem estar. Este estudo objetivou avaliar as propriedades psicométricas da versão brasileira da Mindful Attention Awareness Scale (MAAS). Participaram deste estudo 395 pessoas, divididos entre fumantes, comunidade geral, universitários e meditadores. Foi realizada análise fatorial exploratória para testar a estrutura fatorial da MAAS. A consistência interna foi testada através do alfa de Cronbach, além do teste-reteste e do método das metades, avaliados através de correlação. A validade de construto foi avaliada através da correlação entre a Escala de Bem Estar Subjetivo (EBES) e a MAAS. A validade de critério foi avaliada através da comparação dos escores dos meditadores e dos demais participantes na MAAS. Após a análise fatorial exploratória, a MAAS manteve-se uma escala unidimensional. As medidas de confiabilidade $[\alpha=0,83$; split half $=0,67$ e teste reteste $=0,80(p<0,001)]$ e validade foram satisfatórias, exceto a validade de critério, não confirmada nesta amostra.

Palavras-chave: Atenção plena, consciência plena, MAAS, Psicometria.
\end{abstract}

Although the concept of mindfulness is derived from ancient Buddhist traditions, the use of this concept as a form of health intervention brought the need to define mindfulness in psychological terms (Baer, 2011). Thus, according to the purposes of this study, the concept of
* Mailing address: Departamento de Psicologia, Instituto de Ciências Humanas, Universidade Federal de Juiz de Fora, Rua José Lourenço Kelmer, s/n, Campus Universitário Bairro São Pedro, CEP: 36036-900, Juiz de Fora, MG. E-mail: viviamvb@yahoo.com.br

We express our appreciation to the Fundação de Amparo à Pesquisa do Estado de Minas Gerais (FAPEMIG) and to the Coordenação de Aperfeiçoamento de Pessoal de Nível Superior (CAPES) for financial support, to the Health Secretary of Juiz de Fora for infrastructure, to Larissa Coldibeli, Laís Pereira, Thaís Acácio, Taynara Formagini and Andreza Carvalho for staff support, to Lama Padma Santen and B. Alan Wallace for the meditators interviews, and to Ruth Baer for the valuable suggestions during the development of this work. 
mindfulness that will be used will follow the concepts of Western psychology, in which mindfulness refers to a metacognitive skill, defined by Jon Kabat-Zinn as "paying attention in a particular way, on purpose, in the present moment and nonjudgmentally" (Kabat-Zinn, 1990). Also, mindfulness is defined as a "natural human capacity" (Kabat-Zinn, 2003), cultivated through the formal meditation practice (Baer, Smith, Hopkins, Krietemeyer, \& Toney, 2006; Bishop et al., 2004).

The spread of the concept of mindfulness and its application as a therapeutic intervention in medicine and Western psychology, started through an intervention program designed by Jon Kabat-Zinn in 1979, named Mindfulness-Based Stress Reduction (MBSR). The MBSR was originally developed for management of chronic pain and stress-related illnesses. It consists of eight group sessions of two hours each week, where they are taught formal meditation practices (sitting meditation, walking meditation, yoga and body scan) and ways of including the practice of mindfulness in daily life (Kabat-Zinn, 1990). From the development of MBSR, other programs were created (Mindfulness-Based Cognitive Therapy [MBCT], Mindfulness-Based Relapse Prevention [MBRP], among others), generating a variety of interventions for various other disorders.

Studies have demonstrated that once trait mindfulness involves stepping out of automatic pilot with and an aware observation of the experience without judgment, increases in trait mindfulness mediate treatment outcomes, lead to relaxation, improved self-management (Baer, 2003) and reduction in symptoms across a wide range of populations and disorders (Robins \& Chapman, 2004), which in turn, leads to well-being (Hölzel et al., 2011; Shapiro, Oman, Thoresen, Plante, \& Flinders, 2008).

Hölzel et al. (2011) explored many components through which the practice of mindfulness meditation exerts its effect and proposed the following framework: (a) Attention regulation; (b) Body awareness; (c) Emotion regulation (including reappraisal and exposure, extinction, and reconsolidation); (d) Change in perspective on the self. Toward a stimulus (or emotional trigger) these components interact in chronological order, generating an increase in self-regulation and stress tolerance (Hsu, Collins, \& Marlatt, 2013). Thus, more research is needed with the aim of identifying potential moderators and underlying mechanisms of change. The studies on mindfulness are growing in the international literature, but this is still an incipient topic, particularly in Brazil. Moreover, there is a need to better understand what mindfulness-based interventions work and for whom they serve. This will be possible through the development of valid and reliable instruments that measure mindfulness and its components, as well as associations between them and clinical changes (Didonna, 2009).

In Brazil, there are only two validated instruments to measure and assess the level of mindfulness, the Philadel- phia Mindfulness Scale (Silveira, Castro \& Gomes, 2012), and the Five Facet Mindfulness Questionnaire (Barros, Kozasa, Souza \& Ronzani, 2014). However, the first scale was adapted among people with high levels of schooling, which differs from the reality of the Brazilian population, and the second measures mindfulness in a multidimensional way. Therefore, the relevance of this study is to generate evidence of validity of the Mindful Attention Awareness Scale (MAAS) which is a unidimensional short scale that measures levels of mindfulness (Brown \& Ryan, 2003).

The MAAS, in its original version, is a self-report instrument that aims to measure individual differences in the frequency of states of mind and consciousness through time. For the creation of items, the authors have drawn on their experience and knowledge of mindfulness, the publications on the subject and the existing scales that measure different states of consciousness and came to a set of 184 items. After applying the exclusion criteria and the evaluation by mindfulness experts and college students, the authors comprised a pool of 55 items. After pilot studies with students, items that were not normally distributed or that did not have variability of responses were also excluded, leaving a total of 24 items that were then analyzed (Brown \& Ryan, 2003).

The 24 items were answered by a sample of 313 college students and the results indicated the presence of two factors on the scale. The first explained $95 \%$ of the variance, and then the scale was defined as unidimensional after exploratory factor analysis. Therefore the final scale consisted of 15 items that should be answered on a Likert scale of 6 points, indicating how often participants experienced each of the situations described. The Likert scale ranged from (1) almost always to (6) almost never, with higher scores reflecting higher levels of trait mindfulness. Note that the items in the MAAS describe lack of mindfulness, in order to avoid social desirability in the responses (Brown \& Ryan, 2003).

Besides the MAAS, in order to verify the convergent and discriminant validity and the predictive value of the MAAS in the different populations, the researchers used various measures of self-regulation and well-being. All correlations were in the expected direction, confirming the construct validity of the MAAS. They concluded therefore that the MAAS proved to be a valid and reliable tool for use in both populations of college students as among adults in general. Furthermore, the MAAS properly discriminated groups which presumably must have a differential level of trait mindfulness. The process of the development of this instrument and its psychometric properties are described in the study of Brown and Ryan (2003).

Considering the information above, the overall objective of the present study was to translate, adapt and present evidences of validity of the MAAS for the Brazilian reality, among a population from the general community, people who meditate regularly, college students and a population of tobacco smokers. The specific objectives are (a) 
Barros, V. V., Kozasa, E. H., Souza, I. C. W. \& Ronzani, T. M. (2015). Validity Evidence Validity of the Brazilian Version of the Mindful Attention Awareness Scale (MAAS).

To conduct the translation and adaptation of the MAAS; (b) To evaluate the criterion and construct validity of the MAAS e (c) To evaluate the MAAS reliability.

\section{Method}

\section{Participants}

This study had a convenience sample that comprised (a) smokers $(n=97)$, who entered the specialized treatment service in the month of the data collection, to avoid biases of treatment; (b) General community participants, who were selected on a primary health care unit $(n=123)$, (c) College students $(n=139)$, (d) People who meditate regularly, at least three times a week for at least one year $(n=36)$, selected at a meditation retreat in the city of Viamão in Rio Grande do Sul - Brazil. The diversity of the sample allowed us to assess the adequacy of the scale in people with different levels of meditative practice and education. All participants were over eighteen years once they can give their consent to participate in the research without the need for parents consent.

The sample consisted of 395 participants. Among the participants of the group of college students, 50 also participated in the retest. For the analysis of criterion validity, three participants were included in the general community group, in order to equate the groups.

\section{Main Outcome Measures}

The research instruments were composed of structured and self-report questionnaires:

Socio-demographics. Was used for the characterization of the surveyed sample and included the following variables: age, sex, marital status, occupation, educational level, employment status, household income and years of education.

Fagerström Test for Nicotine Dependence. It was used as an eligibility criterion for the study. It consists of a six questions questionnaire and assesses the degree of nicotine dependence. The scale was translated and validated in Brazil by Carmo and Pueyo, (2002) has a value of internal consistency considered moderate to high $(\alpha=.64)$ and testretest reliability equal to .91 .

Mindful Attention Awareness Scale (MAAS). Unidimensional scale that evaluates the level of mindfulness. It is composed by 15 items to be answered in a six point Likert scale that ranges from (1) almost always to (6) almost never. ( $\alpha=$.87; Brown \& Ryan, 2003).

Subjective Well-Being Scale (SWBS). The SWBS is composed of 62 items. In the first part of the scale the items range from number 1 to 47 and are divided into two factors that describe positive and negative affect. The participant must answer how has he or she been feeling lately in a Likert scale in which 1 means "not at all" and 5 means "extremely". Both these factors have Cronbach's alpha $=.95$. High scores on the factors positive affect and negative affect refer to high level of positive affect and lack of negative affect, respectively. In the second part of the scale, the items range from number 48 to 62 composing the third scaling factor (life satisfaction versus dissatisfaction with life) and describe judgments concerning the evaluation of satisfaction or dissatisfaction with life, and must be answered on a scale in which 1 means "strongly disagree" and 5 means "strongly agree" $(\alpha=.90)$. This scale was adapted and validated in Brazil by Albuquerque and Tróccoli (2004).

\section{Procedures}

The validation of the MAAS was performed using cross-sectional, correlational, quantitative methodology. This study was divided in two phases. The first consisted on the process of translation and cultural adaptation of the instrument and, the second on the study of its psychometric properties, verifying the validity and reliability of the instrument. It is noteworthy that before the survey, the contact with the authors of the instrument, Kirk Warren Brown and Richard Ryan, was established and they authorized the adaptation and validation of the instrument for the populations described above.

In the first phase, the process of translation and cultural adaptation of the instrument was performed, following the five steps standardized by Beaton, Bombardier, Guillemin and Ferraz (2002) and Soares (2011): two translations; synthesis; two back translations; committee of experts and pre-test.

This initial process does not guarantee that the instrument translated and adapted is trustworthy and reliable. A second phase is required, aimed at verifying the psychometric qualities of the instrument (Beaton et al., 2002). The second phase assessed the criterion and construct validity and the reliability of the MAAS. The analysis used for these evaluations are described below.

\section{Data Analysis}

The data were entered by two different typists in a database of the Statistical Package for Social Sciences - SPSS ( , version 15.0. The two versions underwent a process of comparison, through the Software, Epi Info 3.5.3, module Data Compare, to detect any typing errors, which were corrected to form a consolidated database.

After the construction of this database the data were analyzed by descriptive and inferential statistics. Descriptive statistics was used to characterize the sample through the calculation of the mean, median, standard deviation, and frequency for the nominal and ordinal variables (.age, sex, marital status, occupation, educational level, employment status, household income, years of education, level of trait mindfulness and the scores of the SWBS).

For the inferential analysis, we used techniques of visual inspection of Quartile-quartile graphs to assess the distribution of participants' scores on the MAAS and PWBS considering the total sample. In the cases of 
analysis considering subgroups with $n<50$ we used the Kolmogorov-Smirnov test to assess whether the scales scores were normally distributed. We adopted a significance level of $5 \%$ for all statistical tests $(p<.05)$.

\section{Evidence of Construct Validity}

To elucidate the construct validity of the MAAS we performed an exploratory factor analysis on the correlation matrix of the items, with factor extraction through the method of principal components without rotation, to identify the dimensionality of the scale. The method of principal components was chosen once the MAAS is a unidimensional scale. This method analyzes the total variance explained by the items of a single component instead of measuring the common variance existing between factors (Hair, Black, Babin, \& Anderson, 2009). We adopted the factor loading of .4 for the maintenance of the items on the scale.

We also calculated the correlations between total scores of the MAAS and PWBS considering the bivariate Spearman test of correlation to the scores that did not show a normal distribution and Pearson correlation for scores that were normally distributed. In addition, we calculated the correlations between the scores of the MAAS with the scores of each factor of the PWBS.

\section{Evidence of Criterion Validity}

Criterion validity was analyzed by comparing the scores of meditators and the other participants in the MAAS in order to assess whether there was a significant difference between them. Therefore, we used the independent samples $t$ test.

\section{Reliability}

The reliability analysis was performed using the internal consistency estimated by Cronbach's alpha Coefficient, test-retest reliability estimated by Pearson Linear Correlation Coefficient and split half method, estimated by Spearman-Brown Correlation Coefficient.

\section{Ethical Aspects}

This study was approved by the Research Ethics Committee of the Federal University of Juiz de Fora (UFJF; Opinion Document number 120/2011, consistent with the directive in Resolution CNS number 196/96).

After the process of translation and cultural adaptation, an introduction letter was sent to the institutions, explaining the objectives of the present study. Once the data collection was approved, each participant received a Statement of Informed Consent in which the research objectives were explained.

\section{Results}

After completion of the translation and cultural adaptation process, it was consensual to maintain the original name translated and original acronym in order to maintain the international reference for publications as well as to facilitate the identification of the instrument to a national audience, the final result of the name was Mindful Attention Awareness Scale (MAAS).

The instructions for filling out the questionnaire remained the same, with its literal translation. Therefore, the instructions were:

Below is a collection of statements about your everyday experience. Using the 1-6 scale below, please indicate how frequently or infrequently you currently have each experience. Please answer according to what really reflects your experience rather than what you think your experience should be. Please treat each item separately from every other item. Likert scale: (1) almost always, (2) very frequently, (3) somewhat frequently, (4) somewhat infrequently, (5) very infrequently or (6) almost never.

In the pre-test we could ensure that the questionnaire was understandable and that kept the dimensions of the original items. Thus, after the first phase of the research, we concluded the final version of the instrument that was used on the data collection in the second phase. The final version of the instrument (in Portuguese) can be seen in Appendix.

\section{Descriptive Data Analysis}

The sample was mainly composed by women in all groups. Most of the participants, except students were aged between 45 and 64 years old, with mean ages of 48 years $(S D \pm 12)$ among smokers, $49(S D \pm 13)$ among primary care patients and $45(S D \pm 11)$ among meditators. In the students group, the ages varied from 18 to 25 years old, $M_{\text {age }}=22(S D \pm 5)$. The family income and years of schooling were similar among tobacco users and the participants from the primary health care unit (UAPS) and was higher among the students (UFJF) and the experienced meditators (Table 1).

\section{Construct Validity - MAAS}

When performing exploratory factor analysis of the MAAS, the factorial structure of the scale was composed by three factors. However, the first factor grouped 12 items except items 1, 11 and 13, which have not reached the factor loading $\geq .4$. Nevertheless, we chose to maintain the items once they have obtained factor loadings equal to $.39, .36$ and .30 in the first factor, respectively. Also, they were maintained because they add relevant content to the concept of mindfulness. The results of those items should then be interpreted cautiously (Table 2). The unidimensional scale structure explained $31.98 \%$ of the total variance of the scale, and according to the Scree Plot we chose to maintain this structure of one factor. Then, the maximum score that a participant can achieve is 90 points and a minimum of 15 points, indicating the maximum and minimum level of trait mindfulness, respectively. 
Barros, V. V., Kozasa, E. H., Souza, I. C. W. \& Ronzani, T. M. (2015). Validity Evidence Validity of the Brazilian Version of the Mindful Attention Awareness Scale (MAAS).

Table 1

Description of the Demographics of the Participants $(N=395) *$

\begin{tabular}{|c|c|c|c|c|c|c|c|c|}
\hline \multirow{2}{*}{ Variables } & \multicolumn{2}{|c|}{ Smokers } & \multicolumn{2}{|c|}{ UAPS } & \multicolumn{2}{|c|}{ UFJF } & \multicolumn{2}{|c|}{ Meditators } \\
\hline & $n$ & $\%$ & $n$ & $\%$ & $n$ & $\%$ & $n$ & $\%$ \\
\hline \multicolumn{9}{|l|}{ Gender } \\
\hline Female & 63 & 64.9 & 95 & 77.2 & 113 & 81.3 & 22 & 61.1 \\
\hline Male & 34 & 35.1 & 28 & 22.8 & 26 & 18.7 & 14 & 38.9 \\
\hline \multicolumn{9}{|l|}{ Age } \\
\hline$\leq 25$ & 4 & 4,2 & 7 & 5.8 & 126 & 90.6 & - & - \\
\hline Between 26 and 44 & 28 & 29.5 & 31 & 25.6 & 12 & 8.6 & 20 & 55.6 \\
\hline Between 45 and 64 & 58 & 61.1 & 70 & 57.9 & 1 & .7 & 14 & 38.9 \\
\hline$\geq 65$ & 5 & 5.3 & 13 & 10.7 & - & - & 2 & 5.6 \\
\hline \multicolumn{9}{|l|}{ Live with a partner } \\
\hline No & 60 & 63.2 & 52 & 42.3 & 132 & 95 & 24 & 70.6 \\
\hline Yes & 35 & 36.8 & 71 & 57.7 & 7 & 5 & 10 & 29.4 \\
\hline \multicolumn{9}{|l|}{ Family Income (minimum wages) } \\
\hline Up to 3 & 67 & 69.8 & 97 & 78.9 & 31 & 22.3 & 3 & 9.4 \\
\hline 3 to 6 & 20 & 20.8 & 21 & 17.1 & 51 & 36.7 & 6 & 18.8 \\
\hline 6 to 10 & 9 & 9.4 & 5 & 4.1 & 32 & 23.0 & 6 & 18.8 \\
\hline More than 10 & - & - & - & - & 25 & 18.0 & 17 & 53.1 \\
\hline \multicolumn{9}{|l|}{ Schooling } \\
\hline Up to elementary school & 40 & 41.2 & 62 & 50.4 & - & - & - & - \\
\hline Complete or incomplete high school & 36 & 37.1 & 44 & 35.8 & - & - & 1 & 2.8 \\
\hline Complete or incomplete college & 21 & 21.6 & 17 & 13.8 & 139 & 100.0 & 35 & 97.2 \\
\hline
\end{tabular}

Note. *For some variables, the percentage is based in a smaller $n$ because of data missing.

Preliminary evidence of the MAAS construct validity were found considering the statistically significant correlations between the MAAS and PWB, positive affect, negative affect and life satisfaction $(p<.001)$. As expected, the total score of the MAAS was positively correlated with all factors and the overall score of the PWBS $(p<.001)$. The total score of PWBS showed the highest correlation with the total score of the MAAS. The correlation coefficients between the MAAS and other measures are shown in Table 3.

\section{Criterion Validity - MAAS}

In order to find evidences of the MAAS criterion validity we used the group of meditators and randomly selected participants with similar socio-demographics characteristics (gender, age, education and household income) among the other groups. We conducted the chi-square test to check whether the groups were similar and there was no significant difference in any of the socio-demographics variables. Thus the sample used for the analysis of criterion validity was composed of 67 participants, mostly women, people aged up to 44 years old, with family incomes above three times the minimum wage and that at least started college education.

By assessing the existence of significant differences between the group of meditators and other participants in the MAAS scores, we found that there was not a significant difference $p<.05$. The median, mean and standard deviation $(S D)$ of the group of meditators were $64.00,64.44$ and 7.73 , respectively, while these values for the other group were: median (62.00), mean (61.77) and $S D$ (10.48) with $p=.23$, indicating that the scale was not a good predictor of higher levels of trait mindfulness among the population of meditators, who presumably should have a higher level of trait mindfulness.

\section{Reliability-MAAS}

The reliability of the MAAS was determined by calculating the coefficients of internal consistency of the scale. The Cronbach alpha for the total scale, considering its 15 
Table 2

Exploratory Factor Analysis of the 15 Items from the MAAS (N=395)

\begin{tabular}{|c|c|c|c|}
\hline \multirow[b]{2}{*}{ Items } & \multicolumn{3}{|c|}{ Factors } \\
\hline & 1 & 2 & 3 \\
\hline 1) I could be experiencing some emotion and not be conscious of it until some time later & .39 & & .35 \\
\hline $\begin{array}{l}\text { 2) I break or spill things because of carelessness, not paying attention, or thinking of } \\
\text { something else }\end{array}$ & .48 & -.41 & \\
\hline 3) I find it difficult to stay focused on what's happening in the present & 63 & & \\
\hline $\begin{array}{l}\text { 4) I tend to walk quickly to get where I'm going without paying attention to what } \\
\text { I experience along the way }\end{array}$ & .46 & .38 & \\
\hline $\begin{array}{l}\text { 5) I tend not to notice feelings of physical tension or discomfort until they really grab my } \\
\text { attention }\end{array}$ & .44 & .56 & \\
\hline 6) I forget a person's name almost as soon as I've been told it for the first time & .41 & .34 & \\
\hline 7) It seems I am "running on automatic," without much awareness of what I'm doing & .75 & & \\
\hline 8) I rush through activities without being really attentive to them & .74 & & \\
\hline $\begin{array}{l}\text { 9) I get so focused on the goal I want to achieve that I lose touch with what I'm doing right } \\
\text { now to get there }\end{array}$ & .67 & & \\
\hline 10) I do jobs or tasks automatically, without being aware of what I'm doing & .76 & & \\
\hline 11) I find myself listening to someone with one ear, doing something else at the same time & .30 & -.33 & .41 \\
\hline 12) I drive places on 'automatic pilot' and then wonder why I went there & .46 & & \\
\hline 13) I find myself preoccupied with the future or the past & .36 & & .62 \\
\hline 14) I find myself doing things without paying attention & .74 & & \\
\hline 15) I snack without being aware that I'm eating & .52 & & \\
\hline
\end{tabular}

Table 3

Correlations of the MAAS with the Total Score of the PWBS and its Subscales (N=395)

\begin{tabular}{lccccc}
\hline \multicolumn{1}{c}{ Variables } & MAAS total & Positive affect & Negative Affect & Life Satisfaction & PWBS total \\
\hline MAAS total & 1 & - & - & - & - \\
Positive affect & $.36^{*}$ & 1 & - & - & - \\
Negative Affect & $.45^{*}$ & $.50^{*}$ & 1 & - & - \\
Life satisfaction & $.36^{*}$ & $.60^{*}$ & $.63^{*}$ & 1 & - \\
PWBS total & $.47^{*}$ & $.81^{*}$ & $.88^{*}$ & $.83^{*}$ & 1 \\
\hline
\end{tabular}

$* p<.001$

items was .83 and the Spearman-Brown coefficient (split half) was .67. In the test-retest reliability, the Pearson coefficient of linear correlation was $.80(p<.001)$. The means of the individual items ranged from 2.70 to 4.74 , being 3.00 the mid-point of range. The $S D$ ranged from 1.44 to 1.81 .

\section{Discussion}

The present data demonstrate that the methodology proposed by Beaton et al. (2002) and Soares (2011) proved consistent to support the steps of translation and adaptation of the MAAS systematically. The semantic equivalence 
Barros, V. V., Kozasa, E. H., Souza, I. C. W. \& Ronzani, T. M. (2015). Validity Evidence Validity of the Brazilian Version of the Mindful Attention Awareness Scale (MAAS).

criteria were carefully analyzed especially considering the need to keep it consistent with the Brazilian context and understandable to the respondents.

Regarding the sample, there was a great diversity of socio-demographics characteristics, which constitutes one of the strengths of this study, because it allows the instrument to be used by a greater number of people.

Regarding the psychometric properties of the scale, the results indicated that the MAAS showed satisfactory levels of validity and reliability. In terms of construct validity of the MAAS, similarly to the study of Brown and Ryan (2003), it was possible to find a model with a unidimensional factor structure, explaining considerably the total variance of the scale. Likewise the original study, only three items $(1,11$ and 13) that presented factor loadings $<.4$ were maintained because add important contents to the evaluation of the mindfulness construct. Furthermore, item 11 was the only one that needed changes in more than one step during the process of cultural adaptation, which may have influenced its understanding by respondents, impairing its performance in relation to the factor loadings.

By comparing the Brazilian version with other versions validated elsewhere, the value of the total variance explained by the model found in the Brazilian version $(31.98 \%)$ was similar to the value found for the other, which ranged from $(33.3 \%$ to $42.8 \%)$. In general, the values of the factor loadings of the items of the Brazilian version also did not differ from the values found in other validations, including the original scale (Black, Sussman, Johnson, \& Milam, 2012; Brown \& Ryan, 2003; Jermann et al., 2009; MacKillop \& Anderson, 2007; Soler et al., 2012).

The differences in the values of the factor loadings, in the variance explanation and in the dimensionality of the Brazilian MAAS, compared to its original version, may be due to the difficulty of the nonmeditators in understanding terms referring to the kind of attention mindfulness means, once these concepts start to be considered when people start to practice meditation, or due to the difference in interpretation between them and the meditators regarding those terms, which are part of everyday life and are best understood by people who practice meditation. Moreover, according to Lutz, Slagter, Dunne and Davidson (2008) the practice of mindfulness meditation activates brain areas involved in vigilance, monitoring and disengagement of attention from distracting sources during the streaming of experience. Thus the long term practice also contributes to changes in brain and mental functions, reducing the elaborative thinking that normally occurs through the evaluation and interpretation of a selected object (Lutz et al., 2008). This evidence contributes to understand the possible difference in the interpretation of the items between meditators and non meditators, once these tend to evaluate the feelings and behaviors present in the items in an evaluative and elaborative way.

Still considering the construct validity, the Brazilian MAAS correlated positively and significantly with the PWBS, considering both their total score, and its factors.
The correlations between the MAAS and the PWBS were moderate, as expected, indicating that trait mindfulness and subjective well-being are related concepts, and can influence each other, but refer to different concepts. Considering these results and previous studies, the data of the present study indicate that the development of mindfulness skills may contribute to the improvement of mental health, especially on its influence on the psychological well being (Shapiro et al., 2008).

With respect to the analysis performed in order to find evidence of criterion validity, it was observed that the MAAS does not differentiate significantly between experienced meditators from the other participants. The most likely explanation for this is that the MAAS items refer to mindful states during daily activities, and not to perceptions of thoughts and feelings, which is much explored in meditative practices. The results of this study replicate previous results in the literature (MacKillop \& Anderson, 2007). Thus the MAAS may have a clinical utility to objectively measure the level of trait mindfulness, but it is not possible to assess differences in level through the practice of meditation. Another explanation is that our criteria to include participants in the meditators group (at least one year of practice, three times a week) was not enough to generate differences in mindfulness according to the MAAS items. Maybe more experienced meditators could present differences in the MAAS scores compared with non meditators.

With regard to the results of reliability of MAAS, one of the strengths of this study was using more than one method to assess its reliability, once each of them inherently bring possibilities of error and are influenced by other factors (Maroco, Tecedeiro, Martins, \& Meireles, 2008). Accordingly, the reliability of the MAAS can be considered high by the analysis of the Cronbach's alpha of the total scale, which was .83, the Spearman-Brown coefficient (split half) which was .67 and test-retest, in which the value of Pearson linear correlation coefficient was $.80(p<.001)$. Considering these values, the Brazilian MAAS was closely equated to the original scale in which the values were .82 for a population of college students, .87 for the general population and .81 in the test-retest reliability (Brown \& Ryan, 2003).

In addition it was observed that the results of reliability of the present study are very similar to the other versions of the MAAS, in which the values of Cronbach's alpha ranged from .77 in a population of recruits for military service to .93 in a population of Chinese adolescents (Black et al., 2012; Brown, West, Loverich, \& Biegel, 2011; Hansen, Lundh, Homman, \& Wangby-Lundh, 2009; Jermann et al., 2009; MacKillop \& Anderson, 2007; Soler et al., 2012). In the test-retest reliability, the values found in the literature ranged from .35 to .79 (Black et al., 2012; Brown et al., 2011).

This study provided important results concerning the study of scales that aim to assess trait mindfulness, which may also help in the operationalization of this concept. 
Also, it can be considered a pioneering study in a recent line of studies that aim to test the psychometric properties of these instruments in a demographically diverse population. This was the first study that rigorously evaluated the psychometric properties of the MAAS among Brazilian participants.

Besides the strengths of this study, it also has some limitations. There is a need of complementary investigations like the confirmatory factorial analysis and the utilization of analysis with more consistent methods such as policoric factorial analysis and the Item Response Theory (IRT) with larger samples. Also, multiple regression analysis that consider other mindfulness related constructs are needed to explore the implications of this construct in the mental health field, in the emotion regulation and in the cognitive functioning, contributing to a better understanding of the human behavior.

\section{Conclusion}

The present study achieved the goals of adapting and evaluating the psychometric properties of MAAS, converting it into an appropriate tool to measure trait mindfulness among psychology students, smokers, Brazilian meditators and general population. This study may help in providing subsidies to the progress of research in this area by examining the empirical relationships between trait mindfulness and mental health. This study provided initial evidence that trait mindfulness is positively associated with subjective well-being and suggests that this construct has promising role for future etiologic studies. However, it is important that these instruments continue to be tested for its psychometric properties in different populations and sociocultural contexts of Brazilian reality.

\section{References}

Albuquerque, A. S., \& Tróccoli, B. T. (2004). Desenvolvimento de uma escala de bem-estar subjetivo. Psicologia: Teoria e Pesquisa, 20, 153-164. doi:10.1590/S010237722004000200008

Baer, R. A. (2003). Mindfulness training as a clinical intervention: A conceptual and empirical review. Clinical Psychology: Science and Practice, 10(2), 125-143. doi:10.1093/clipsy/ bpg015

Baer, R. A. (2011). Measuring mindfulness. Contemporary Buddhism, 12(1), 241-261. doi:10.1080/14639947.2011.564842

Baer, R. A., Smith, G. T., Hopkins, J., Krietemeyer, J., \& Toney, L. (2006). Using self-report assessment methods to explore facets of mindfulness. Assessment, 13(1), 27-45. doi:10.1177/1073191105283504

Barros, V. V., Kozasa, E. H., Souza, I. C. W., \& Ronzani, T. M. (2014). Validity Evidence of the Brazilian Version of the Five Facet Mindfulness Questionnaire (FFMQ). Psicologia: Teoria e Pesquisa, 30(3), 317-327.

Beaton, D., Bombardier, C., Guillemin, F., \& Ferraz, M. B. (2002). Recommendations for the cross-cultural adaptation of health status measures. Toronto, CA: Institute for Work \& Health. Retrieved from http://www.dash.iwh.on.ca
Bishop, S. R., Lau, M., Shapiro, S., Carlson, L., Anderson, N. D., Carmody, J., ...Devins, G. (2004). Mindfulness: A proposed operational definition. Clinical Psychology: Science \& Practice, 11, 230-241. doi:10.1093/clipsy/bph077

Black, D. S., Sussman, S., Johnson, C. A., \& Milam, J. (2012). Psychometric assessment of the Mindful Attention Awareness Scale (MAAS) among Chinese adolescents. Assessment, 19, 42-52. doi:10.1177/1073191111415365

Brown, K. W., \& Ryan, R. M. (2003). The benefits of being present: Mindfulness and its role in psychological well-being. Journal of Personality and Social Psychology, 84(4), 822-848. doi:10.1037/0022-3514.84.4.822

Brown, K. W., West, A. M., Loverich, T. M., \& Biegel, G. M. (2011). Assessing adolescent mindfulness: Validation of an adapted Mindful Attention Awareness Scale in adolescent normative and psychiatric populations. Psychological Assessment, 23, 1023-1033. doi:10.1037/a0021338

Carmo, J. T. D., \& Pueyo, A. A. (2002). A adaptação ao português do Fagerström Test for Nicotine Dependence (FTND) para avaliar a dependência e tolerância à nicotina em fumantes brasileiros. Revista Brasileira de Medicina, 58(1-2), 73-80.

Didonna, F. (2009). Clinical handbook of mindfulness. New York: Springer. doi:10.1007/978-0-387-09593-6

Hair, J. F., Black, W. C., Babin, B. J., \& Anderson, R. E. (2009). Multivariate data analysis. ( $7^{\text {th }}$ ed.). Indianapolis, IN: Prentice Hall.

Hansen, E., Lundh, L.-G., Homman, A., \& Wangby-Lundh, M. (2009). Measuring mindfulness: Pilot studies with the Swedish versions of the Mindful Attention Awareness Scale and the Kentucky Inventory of Mindfulness Skills. Cognitive Behaviour Therapy, 38, 2-15. doi:10.1080/16506070802383230

Hölzel, B. K., Lazar, S. W., Gard, T., Schuman-Olivier, Z., Vago, D. R., \& Ott, U. (2011). How does mindfulness work? Proposing mechanisms of action from a conceptual and neural perspective. Perspectives on Psychological Science, 6, $537-$ 559. doi:10.1177/1745691611419671

Hsu, S. H., Collins, S. E., \& Marlatt, G. A. (2013). Examining psychometric properties of distress tolerance and its moderation of mindfulness-based relapse prevention effects on alcohol and other drug use outcomes. Addictive Behaviors, 38, 1852-1858. doi:10.1016/j.addbeh.2012.11.002

Jermann, F., Billieux, J., Larøi, F., d'Argembeau, A., Bondolfi, G., Zermatten, A., \& Van der Linden, M. (2009). Mindful Attention Awareness Scale (MAAS): Psychometric properties of the French translation and exploration of its relations with emotion regulation strategies. Psychological Assessment, 21, 506-514. doi:10.1037/a0017032

Kabat-Zinn, J. (1990). Full catastrophe living: Using the wisdom of your body and mind to face stress, pain and ilness. Peaslake, UK: Delta.

Kabat-Zinn, J. (2003). Mindfulness-based interventions in context: Past, present, and future. Clinical Psychology: Science and Practice, 10, 144-156. doi:10.1093/clipsy.bpg016

Lutz, A., Slagter, H. A., Dunne, J. D., \& Davidson, R. J. (2008). Attention regulation and monitoring in meditation. Trends in Cognitive Science, 12, 163-169. doi:10.1016/j. tics.2008.01.005

MacKillop, J., \& Anderson, E. J. (2007). Further psychometric validation of the Mindful Attention Awareness Scale (MAAS). Journal of Psychopathology and Behavioral Assessment, 29, 289-293. doi:10.1007/s10862-007-9045-1

Maroco, J., Tecedeiro, M., Martins, P., \& Meireles, A. (2008). O Burnout como factor hierárquico de $2^{\mathrm{a}}$ ordem da Escala de Burnout de Maslach. Análise Psicológica, 4(26), 639-649. 
Barros, V. V., Kozasa, E. H., Souza, I. C. W. \& Ronzani, T. M. (2015). Validity Evidence Validity of the Brazilian Version of the Mindful Attention Awareness Scale (MAAS).

Robins, C. J., \& Chapman, A. L. (2004). Dialectical behavior therapy: Current status, recent developments, and future directions. Journal of Personality Disorders, 18(1), 73-89. doi:10.1521/pedi.18.1.73.32771

Shapiro, S. L., Oman, D., Thoresen, C. E., Plante, T. G., \& Flinders, T. (2008). Cultivating mindfulness: Effects on well-being. Journal of Clinical Psychology, 64, 840-862. doi:10.1002/jclp.20491

Silveira, A. C., Castro, T. G., \& Gomes, W. B. (2012). Adaptação e validação da Escala Filadélfia de Mindfulness para adultos brasileiros. Psico-USF, 17, 215-223. doi:10.1590/S141382712012000200005
Soares, R. G. (2011). Validação da versão brasileira da "Escala de Estigma Internalizado de Transtorno Mental (ISMI) adaptada para dependentes de substâncias" (Dissertação de mestrado, Universidade Federal de Juiz de Fora, MG, Brasil). Recuperada em http://www.ufjf.br/crepeia/files/2009/09/ Validacao-escala-estigma-ismi.pdf

Soler, J., Tejedor, R., Feliu-Soler, A., Pascual, J. C., Cebolla, A., Soriano, J., ...Perez, V. (2012). Psychometric proprieties of Spanish version of Mindful Attention Awareness Scale (MAAS). Actas Españolas de Psiquiatría, 40(1), 19-26.

Recebido: 09/01/2014 Aceite final: 16/01/2014

\section{Appendix}

Brazilian Version of the MAAS and Instructions for Scoring

\begin{tabular}{cccccc}
\hline $\mathbf{1}$ & $\mathbf{2}$ & $\mathbf{3}$ & $\mathbf{4}$ & $\mathbf{5}$ & $\mathbf{6}$ \\
\hline $\begin{array}{c}\text { Quase } \\
\text { sempre }\end{array}$ & $\begin{array}{c}\text { Muito } \\
\text { Frequentemente }\end{array}$ & $\begin{array}{c}\text { Relativamente } \\
\text { Frequente }\end{array}$ & Raramente & Muito raramente & Quase nunca \\
\hline
\end{tabular}

1 Eu poderia experimentar alguma emoção e só tomar consciência dela algum tempo depois

2 Eu quebro ou derramo as coisas por falta de cuidado, falta de atenção, ou por estar pensando em outra coisa

3 Eu tenho dificuldade de permanecer focado no que está acontecendo no presente

4 Eu costumo andar rápido para chegar ao meu destino, sem prestar atenção ao que eu vivencio no caminho

5 Eu não costumo notar as sensações de tensão física ou de desconforto até que elas realmente chamem a minha atenção

6 Eu esqueço o nome das pessoas quase imediatamente após eu tê-lo ouvido pela primeira vez

7 Parece que eu estou "funcionando no piloto automático", sem muita consciência do que estou fazendo

8 Eu realizo as atividades de forma apressada, sem estar realmente atento a elas

9 Eu fico tão focado no objetivo que quero atingir, que perco a noção do que estou fazendo agora para chegar lá

10 Eu realizo trabalhos e tarefas automaticamente, sem estar consciente do que estou fazendo

11 Eu me percebo ouvindo alguém falar e fazendo outra coisa ao mesmo tempo

12 Eu dirijo no "piloto automático" e depois penso porque eu fui naquela direção

13 Encontro-me preocupado com futuro ou com o passado

14 Eu me pego fazendo coisas sem prestar atenção

15 Eu como sem estar consciente do que estou comendo

\begin{tabular}{|c|c|c|c|c|c|}
\hline 1 & 2 & 3 & 4 & 5 & 6 \\
\hline 1 & 2 & 3 & 4 & 5 & 6 \\
\hline 1 & 2 & 3 & 4 & 5 & 6 \\
\hline 1 & 2 & 3 & 4 & 5 & 6 \\
\hline 1 & 2 & 3 & 4 & 5 & 6 \\
\hline 1 & 2 & 3 & 4 & 5 & 6 \\
\hline 1 & 2 & 3 & 4 & 5 & 6 \\
\hline 1 & 2 & 3 & 4 & 5 & 6 \\
\hline 1 & 2 & 3 & 4 & 5 & 6 \\
\hline 1 & 2 & 3 & 4 & 5 & 6 \\
\hline 1 & 2 & 3 & 4 & 5 & 6 \\
\hline 1 & 2 & 3 & 4 & 5 & 6 \\
\hline 1 & 2 & 3 & 4 & 5 & 6 \\
\hline 1 & 2 & 3 & 4 & 5 & 6 \\
\hline 1 & 2 & 3 & 4 & 5 & 6 \\
\hline
\end{tabular}

Note. To make the score add up the answers and divide by 15, higher values represent higher levels of mindfulness. 